\title{
PROMOSI WISATA KULINER KHAS BANTEN DI MEDIA ONLINE SEBAGAI PENDUKUNG PARIWISATA BANTEN
}

\author{
Dewi Widowati \\ Pascasarjana Universitas Sahid \\ Sahid Sudirman Residence Lt. 5 No. 1, Jl. Jend. Sudirman No. 86 Jakarta \\ Email korespondensi: dewiwidowati68@gmail.com
}

\begin{abstract}
ABSTRAK
Bidang pariwisata menjadi bidang yang saat ini mendapat perhatian, baik di tingkat pusat maupun daerah. Upaya yang dilakukan oleh Provinsi Banten melalui kegiatan promosi dalam mengkomunikasikan pariwisata Banten untuk diperkenalkan ke tingkat nasional maupun internasional. Teori yang digunakan dalam pembahasan ini yaitu Teori Cyber Media. Bagaimana kemudian upaya ini dintegrasikan dengan para pemangku kepentingan terkait pariwisata Banten. Metode yang digunakan deskriptif interpretatif. Data diperoleh melalui kepustakaan mengenai pariwisata, khususnya wisata kuliner di Banten. Pembahasan makalah ini dengan menggunakan studi literatur. Bagaimana pentingnya media online dalam upaya mempromosikan wisata kuliner di Banten. Serta pentingnya sinergisitas para pemangku kepentingan, tentang bagaimana, dan apa yang telah dilakukan, sedang dilakukan, dan yang akan dilakukan terhadap upaya memajukan dan mengembangkan pariwisata di Banten terutama bidang wisata kuliner. Data diperoleh melalui kepustakaan mengenai pariwisata, khususnya wisata kuliner di Banten.
\end{abstract}

Kata kunci: Computer Mediated Communication; Komunikasi pariwisata; Media online.

\begin{abstract}
The tourism sector is becoming a field that is currently receiving attention, both at the central and regional levels. The efforts made by Banten Province through promotional activities in communicating Banten tourism to be introduced to the national and international level. The theory used in this discussion is Cyber Media Theory. How then this effort is integrated with stakeholders related to Banten tourism. The method used is interpretive descriptive. Data obtained through the literature on tourism, especially culinary tourism in Banten. Discussion of this paper using the study of literature. How important is online media in promoting culinary tourism in Banten. As well as the importance of the synergy of the stakeholders, about how, and what has been done, is being done, and which will be done towards efforts to promote and develop tourism in Banten, especially in the culinary tourism sector. Data obtained through the literature on tourism, especially culinary tourism in Banten.
\end{abstract}

Keywords: Computer Mediated Communication; Tourism communication; Online media. 


\section{PENDAHULUAN}

Memajukan, mengembangkan dan memperkenalkan kiprah sebuah negara dapat dilakukan melalui berbagai bidang, baik itu politik, ekonomi, sosial maupun budaya. Bidang yang saat ini menjadi perhatian pemerintah untuk mengembangkan dan memajukan Indonesia di kiprah internasional yaitu bidang pariwisata, yang dapat dimasukkan dalam sisi bidang budaya. Hal ini ditopang dengan perkembangan dan kemajuan teknologi komunikasi di era disrupsi yang semakin pesat dan canggih, yang memungkinkan upaya memperkenalkan pariwisata suatu daerah menjadi mudah tersebar dan cepat, tinggal bagaimana pihak-pihak yang berhubungan langsung dengan pengelolaan pariwisata dapat mengelolanya dengan baik, serius dan tepat sasaran.

Bila dikaitkan dengan keilmuan, pariwisata merupakan sebuah kajian ilmu yang relatif baru. Namun demikian, berbagai pihak telah berupaya untuk menjadikan bidang pariwisata sebagai disiplin ilmu yang mandiri yang bersifat interdisiplin dan multidisiplin. Kemandirian sebuah bidang ilmu sudah pasti tidak menjadikannya sebagai ilmu yang benar-benar mandiri, karena walau bagaimanapun sebuah ilmu akan berkaitan dengan ilmu-ilmu lainnya. Dalam hal ini bidang pariwisata juga tidak akan lepas dari ilmu psikologi, antropologi, sosiologi, ekonomi, politik dan komunikasi. Dengan demikian dapat terjadi integrasi ilmu yang dapat lebih memaksimalkan potensi dari ilmu itu sendiri. (Winangsih, 2010:v).

Dengan demikian tak dapat dipungkiri lagi diperlukan integrasi antara konsep komunikasi dan pariwisata, yaitu "komunikasi pariwisata", untuk dapat mempercepat upaya pengembangan kepariwisataan di Indonesia. Bidang komunikasi pariwisata yang saat ini ditunjang dengan teknologi yang canggih memungkinkan Pemerintah mampu bergerak lebih cepat memperkenalkan Indonesia ke dunia internasional melalui pariwisatanya. Dengan wilayah yang luas, sebagai negara kepulauan terbesar di dunia, Indonesia memiliki tempat-tempat indah yang dapat dijadikan sebagai objek wisata dan dapat diandalkan. Salah satunya adalah Provinsi Banten. Saat ini beberapa objek wisata mulai digarap serius oleh Pemerintah Provinsi Banten, diantaranya Tanjung Lesung, Masjid Agung Banten, Pantai Carita dan Anyer dengan mercu suarnya, Sentra Batik Banten, Kampung Baduy, Ujung Kulon dan juga wisata kuliner yang menjadi ciri khas Banten, seperti Sate Bandeng, Ketan Bintul, Rabeg dan beberapa makanan camilan lainnya seperti kue cuwer dan apem. Ini dapat menjadi potensi Banten dalam bidang kepariwisataan, khususnya wisata kuliner.

Sejalan dengan perkembangan pariwisata di Provinsi Banten, dengan segala kelebihan dan kekurangannya masih membutuhkan penanganan dan perhatian serius dari segenap para pemangku kepentingan atau konstituen, termasuk kaum intelektual, para akademisi dan keterlibatan warganya. Bidang public relations (PR) pun dapat menjadi bagian dalam upaya mengembangkan pariwisata di Banten. Seperti diketahui bahwa public relations merupakan spesialisasi dari ilmu komunikasi. Public relations atau biasa juga dikenal dengan istilah hubungan masyarakat merupakan fungsi manajemen yang membentuk dan memelihara hubungan saling menguntungkan antara organisasi dan masyarakat, yang menjadi sandaran keberhasilan atau kegagalannya. (Cutlip, Center \& Broom, 2000:5). Inti dari PR itu sendiri adalah membina hubungan yang baik dan membangun itikad baik di antara para stakeholder yang terlibat dalam perusahaan, lembaga, organisasi, dan lain-lain. Melalui perspektif PR, maka hubungan timbal balik menjadi hal yang utama, di mana orang-orang yang terlibat dalam kegiatan-baik di perusahaan, lembaga, organisasi - dapat saling menghormati, saling pengertian, saling 
mendukung. Hal tersebut dapat dibangun dengan mengelola komunikasi dua arah antara pemerintah, perusahaan, lembaga, institusi, juga tokoh masyarakat.

Dengan demikian kaitan PR dalam upaya untuk mengembangkan komunikasi pariwisata adalah membangun komunikasi di antara pihak-pihak yang terlibat dalam upaya pengembangan pariwisata tersebut. Pihak-pihak tersebut yaitu Pemerintah Banten, Pengusaha, Masyarakat, dan para tokoh masyarakat yang diharapkan dapat menjadi jembatan penghubung dalam memperkenalkan objek wisata dan juga wisata kuliner di Banten. Peranan Pemerintah Daerah Provinsi Banten dalam memprioritaskan pengembangan pariwisata daerah ini dengan sungguh-sungguh menjadi kata kunci. Aparatur dari SKPD-SKPD yang terkait mulai dari Dinas PU, Dinas Pendidikan, Dinas Perindustrian, Dinas Perhubungan dan Kominfo, serta Dinas-dinas lainnya yang ada di tingkat Kabupaten/Kota dapat bersinergi dengan koordinator Dinas Pariwisata Provinsi Banten. Tidak mudah memang. Namun indikasi peran yang harus dibangun dari dalam (Pemerintah) mutlak dilakukan. Gubernur Wahidin Halim, sebagai Kepala Daerah memiliki figur kepemimpinan yang cukup menonjol dan tegas dalam kiprahnya beberapa bulan memimpin Banten. Hal inilah yang diharapkan mampu menggerakkan geliat dinamika pariwisata Banten.

Pejabat Gubernur harus mampu mengembangkan apa yang disebut dengan Role performance dan Role Relationships; peranan yang harus dilakukan oleh anggota-anggota (pegawai-pegawainya/SKPD/Dinas) sebagai wujud nyata dari suatu peran atas tugas masing-masing. Sedangkan role relationship mengacu pada bagaimana para anggotanya berinteraksi. Role relationship menurut Soetarto (1985) dalam kutipan Suryana (2004:366) adalah hubungan antar individu yang memiliki peranan berbeda dalam suatu organisasi. Kemampuan ini dapat berjalan efektif apabila pimpinan mengembangkan peran komunikasi tidak hanya dalam bentuk rapat (rapat dinas, rapat kerja) dengan menghadirkan pimpinan SKPD, tetapi lebih penting lagi implementasinya di lapangan yang menghasilkan target/sasaran yang dicapai (objective goal). Selain hal itu, kemampuan kepala daerah dalam aspek pengendalian bagaimana para bawahannya terkontrol termasuk progres atau kemajuan programnya. Karena bidang pariwisata melibatkan banyak pemangku kepentingan, maka sepatutnya faktor koordinasi dan sosialisasi menjadi hal yang harus dilakukan secara berkesinambungan, sebagai aktivitas yang berjalan dengan melihat perbaikan dan hasilnya yang terus menerus diawasi (supervisi). Seperti proses PR yang dikatakan oleh Phillip Lesley dengan cyrcle of PR (Ardianto:2004) bahwa Public Relations tidak pernah berhenti dalam melakukan perbaikan dan evaluasi, demikian pula bila hal ini diterapkan dalam bidang pariwisata Banten.

Upaya yang dilakukan bidang PR dalam implementasi komunikasi pariwisata yaitu di antaranya dapat melalui promosi pariwisata mengenai objek-objek wisata yang terdapat di Provinsi Banten. Melalui pesan-pesan promosi yang gencar dilakukan diharapkan memberikan pemahaman kepada masyarakat untuk turut serta menggaungkan pariwisata di Banten. Berbicara tentang promosi, tidak akan lepas dari pengemasan pesan dan pengelolaan pesan. Menurut Winangsih (2010:23), beberapa indikator tentang kampanye promosi untuk, yaitu: 1)Kampanye merupakan serangkaian kegiatan komunikasi (movement action); 2) Sifatnya direncanakan secara teratur dan matang; 3) Melalui pesan-pesan khusus atau topik-topik yang dipilih sesuai dengan tema kampanye; 4) Dilakukan dalam waktu tertentu; 5) Menggunakan agen perubahan; 6) Ditujukan kepada kelompok sasaran tertentu; 7) Keuntungan lebih ditekankan pada audience atau sasaran, 8) Ditinjau dari jenis kampanye ada dua macam, yaitu: a. Kampanye informasi, 
bertujuan untuk pencapaian kesejahteraan khalayak/masyarakat; dan b. Kampanye ideologi politik, yang bertujuan untuk membangkitkan perjuangan bangsa. Dengan demikian kampanye pariwisata sangat penting dilakukan secara berkesinambungan dan gencar, disesuaikan dengan pertimbangan pada tujuan pemerintah pusat maupun daerah untuk memperkenalkan pariwisata Banten. Pemerintah daerah dan para pemangku kepentingan yang terlibat dalam program ini merupakan "agen perubahan" yang siap merubah dan membangun pariwisata Banten. Harapan ke depannya pariwisata di Kota Serang Banten, khususnya wisata kuliner-nya dapat dikenal luas, baik lokal maupun nasional.

Tujuan dari pembahasan ini di antaranya: 1) Untuk menganalisis bagaimana upaya promosi wisata kuliner yang dilakukan oleh Pemerintah Provinsi Banten melalui Media online. 2) Untuk mengevaluasi bagaimana upaya promosi wisata kuliner dapat mengembangkan potensi Banten sebagai Wisata Kuliner.

\section{Penelitian Terdahulu}

Adanya penelitian terdahulu dapat membantu dalam melakukan penelitian selanjutnya. Penelitian terdahulu yang dipaparkan menggunakan teori yang berbeda. Berikut ini pemaparan mengenai penelitian yang dilakukan oleh Betari Kiranasari (2013), dengan judul penelitian: Faktor-faktor yang Menentukan Online Seller Memilih Jejaring Instagram Sebagai Media Promosi Online Shop (Studi Deskriptif Kualitatif Mengenai Faktor-faktor yang Menentukan Toko Online Shop di Yogyakarta Memilih Media Promosi Instagram). Penelitian ini menyorot Instagram sebagai salah satu jejaring sosial yang banyak diminati masyarakat untuk mempromosikan produknya melalui bisnis online. Metode yang digunakan dalam penelitan ini adalah metode kualitatif, dengan Teori Uses and Gratification. Sementara subjek penelitian yaitu para online seller pengguna instagram yang berdomisili di Yogyakarta. Temuan dalam penelitian ini bahwa factor kebutuhan dari Uses and Gratification (kognitif, afektif, integrasi personal, pelepasan ketegangan) cocok dengan yang ditemukan seller dalam memilih instagram sebagai media promosi online shop-nya. Di luar factor tersebut, ditemukan pula factorfaktor lain di lapangan, yaitu faktor kemudahan akses, biaya relatif murah, dan lifestyle. Saran yang diajukan dalam penelitian ini untuk online seller, yaitu memperbaiki tampilan produk secara visual dan mengurangi penggunaan hashtag yang terlampau ramai agar tidak terjadi noise dalam foto produk yang ditampilkan.

Penelitian terdahulu tersebut berbeda dalam penggunaan teori tetapi sama dalam pembahasan makalah ini secara umum, yaitu mendeskripsikan bagaimana media online memiliki kekuatan dalam upaya mempromosikan produk. Sifatnya yang audio-visual memungkinkan orang menampilkan produk beserta gambar dan tulisan, yang ditampilkan dengan warna-warna yang menarik. Pembahasan makalah ini lebih fokus pada wisata kuliner di Banten yang dipromosikan melalui berbagai media online, seperti Facebook (FB), Instagram (IG), Line, WhatsApp (WA). Serta penggunaan Teori Cyber Media.

\section{Bidang Pariwisata di Era Disrupsi}

Sebelum membahas lebih jauh mengenai pariwisata, perlu juga membahas secara singkat mengenai perkembangan teknologi komunikasi yang juga disebut era digital atau juga era dirupsi. Perubahan sangat cepat ini menggunakan juga istilah revolusi, yang kemudian dikaitkan dengan industri menjadi revolusi industri. Selanjutnya muncul istilah industri 4.0 yang sebenarnya berawal dari sebuah proyek yang diprakarsai oleh 
pemerintah Jerman untuk mempromosikan komputerisasi manufaktur. Revolusi industri dari industry 1.0, 2.0, 3.0, hingga 4.0. Fase industri merupakan real change dari perubahan yang ada. Industri 1.0 ditandai dengan mekanisme produksi untuk menunjang efektivitas dan efisiensi aktivitas manusia. Industri 2.0 dicirikan oleh produksi massal dan standarisasi mutu. Industri 3.0 ditandai dengan penyesuaian massal dan fleksibilitas manufaktur berbasis otomasi dan robot. Industri 4.0 selanjutnya hadir menggantikan industry 3.0 yang ditandai dengan cyber fisik dan kolaborasi manufaktur (Hermann et.al, 2015; Irianto, 2017).

Perubahan teknologi ini tidak dapat dielakkan sehingga setiap kegiatan di bidang apapun pada akhirnya mulai bergeser ke pemanfaatan digital. Termasuk bidang pariwisata dengan memanfaatkan internet dalam mempromosikan destinasi wisata, baik itu wisata bahari, wisata religi, wisata sejarah, wisata belanja, maupun wisata kuliner.

\section{Komunikasi Dalam Kegiatan Promosi di Media Online}

Kata komunikasi sering sekali didengar dan digunakan. Komunikasi digunakan oleh manusia dalam menyampaikan ide, gagasan yang ada didalam benak seseorang yang disampaikan kepada orang lain. Menurut Carl I. Hovland (Mulyana, 2005:62) Komunikasi adalah proses yang memungkinkan seseorang (komunikator) menyampaikan rangsangan (biasanya lambang-lambang verbal) untuk mengubah perilaku orang lain (komunikate). Sementara Bernard Berelson dan Gary A. Steiner, bahwa komunikasi : transmisi informasi , gagasan, emosi, keterampilan, dan sebagainya, dengan menggunakan simbol-simbol, kata-kata, gambar, figure, grafik, dan sebagainya. Tindakan atau proses transmisi itulah yang biasanya disebut komunikasi.

Dengan demikian secara tidak disadari saat seseorang menyampaikan pesan atau informasi kepada orang lain terjadi pengoperan lambang-lambang, baik verbal maupun noverbal. Lambang verbal yaitu secara lisan (ketika berbicara) dan tulisan. Sementara lambang nonverbal, yaitu berupa tanda, simbol maupun mimik wajah, gerak tubuh seseorang. Penyampaian pesan atau informasi melalui media massa, yang saat ini lebih gencar dilakukan melalui media online, juga sarat sekali dengan pesan simboliknya lewat gambar, kata-kata yang dibuat sedemikian rupa hingga menarik orang yang melihat. Dengan harapan mereka yang melihat dapat terpengaruh dan pada akhirnya berperilaku seperti yang diharapkan oleh orang atau mereka yang menyampaikan pesan atau informasi. Begitu juga dengan iklan-iklan yang ditayangkan lewat media online, netizen akan cenderung mudah terpengaruh dikarenakan sifat komunikasinya yang audio-visual yang cenderung bergerak dan penuh warna.

Promosi adalah kegiatan yang dilakukan untuk memperkenalkan produk kepada konsumen, hingga terjadi penjualan produk. Promosi atau disebut juga outdoor advertising (Soemanagara, 2012:29) termasuk bagian dari persuasive communication. Tidak saja digunakan untuk memperkenalkan produk, tetapi juga digunakan untuk menginformasikan sebuah kegiatan seperti: pentas musik, pertandingan, kompetisi olahraga. Maksud dari promosi agar upaya penjualan dapat lebih maksimal lagi ketimbang hanya menjual saja tanpa mempromosikan produk. Promosi juga merupakan aspek pemasaran umum bahwa manajemen promosi berhubngan dengan ekplisitas. Promosi meliputi praktek periklanan, penjualan peorangan, promosi penjualan, publisitas, dan point of purchase communication. (Shimp, 2003:596)

Promosi penjualan produk dapat dilakukan dengan berbagai cara, baik secara langsung face to face antara pembeli dan penjual, maupun penawaran melalui media 
massa. Dalam hal ini media massa terdiri dari media massa cetak (surat kabar, majalah, brosur, tabloid, leaflets, spanduk) maupun elektonik (radio, televise, video, film, dan internet dengan berbagai aplikasinya seperti instagram, facebook, line, whatsApp, dan lain-lain). Seiring dengan perkembangan teknologi komunikasi yang sangat pesat, khusus media internet ini memiliki kekuatan yang khas di mana netizen (khalayak internet) dapat berselancar mencari berbagai informasi ke dunia lain hanya melalui komputer atau sebuah ponsel saja.

Saat ini tak terhitung jumlah orang yang menggunakan media online. Bagi pemilik produk dapat mengiklankan atau mempromosikan barang atau produknya, dan bagi netizen dapat mencari informasi mengenai produk yang dinginkan sebelum memutuskan untuk membeli (Shimp ,2012:544). Dengan demikian orang-orang yang membutuhkan informasi tentang sesuatu yang dicari akan mudah mendapatkannya, tidak perlu datang ke toko atau tempat yang menjual barang tersebut. Selain itu, dapat dengan cepat membandingkan harga maupun jenis produk atau barang yang sama di situs yang lain.

\section{Teori Computer Mediated Communication}

Perkembangan teknologi komunikasi yang sangat pesat pada akhirnya memunculkan kajian baru, yaitu komunikasi yang termediasi melalui komputer, atau yang disebut sebagai Computer Mediated Communication (CMC), yang menekankan bagaimana komputer memediasi proses komunikasi. Holmes (2005:55) menegaskan bahwa ada empat poin penting mengenai CMC, yaitu: 1)Memfokuskan pada keunikan komunikasi yang terjadi di cyberspace; 2) Lebih mengkhususkan diri pada term "interaksi" dibanding "integrasi", yang lebih mengangkat beragam bentuk interaksi individu dibandingkan semua konteks serta ritual sosial di mana interaksi tersebut memiliki makna; 3) Tidak seperti "media studies" beberapa pembahasan CMC mengungkap bagaimana factor-faktor Eksternal memengaruhi kegiatan komunikasi. Dengan menganalisis broadcast, kenyataannya sangat sedikit yang mengeksplorasi bagaimana faktor-faktor eksternal tersebut memengaruhi konten media, sementara media konten itu sendiri dinilai dari bagaimana ia merefleksikan segala sesuatunya di luar media atau realitas nonmedia. 4) Dengan sedikit mengabaikan beragam bentuk interaksi sosial yang mungkin mendukung perspektif $\mathrm{CMC}$, bahwa perspektif ini memfokuskan pada integrasi informasi di mana komunikasi yang terjadi melalui medium komputer berdasarkan pada proses informasi yang dapat dijumpai dalam beragam bentuk.

Dengan kehadiran internet sebagai media baru (new media) memberikan kesempatan kepada siapa saja untuk memperoleh informasi apa saja tanpa harus bertemu atau bertatap muka dengan pemilik akun atau orang/pihak yang memuat informasi tersebut. Bagi Jordan (2009) media baru memberikan informasi pribadi jauh lebih banyak (identity fluidity) dibanding media tradisonal pada umumnya. Jika dalam dunia nyata informasi diri baru terungkap seiring dengan intensitas dan interaksi antarentitas (Mead, 1934; Altman\&Taylor,1987;Berger 1988), sedangkan dalam interaksi di internet informasi menjadi sedemikian banyak terbuka (Nasrullah,2012:98). Dengan kata lain pihak-pihak yang berkomunikasi tidak perlu lagi bertemu secara fisik di dunia nyata maupun di dunia virtual, namun cukup membuka halaman situs yang memuat informasi mengenai hal atau sesuatu yang dicari. 


\section{Pengertian Pariwisata}

Secara etimologis, kata parwisata berasal dari bahasa Sangskerta dengan kata, yang terdiri dari kata pari dan wisata. Pari berarti banyak, berkali-kali, berputar-putar, lengkap (ingat kata paripurna), sedangkan wisata berarti perjalanan, bepergian yang sinonim dengan kata travel dalam bahasa Inggris. Dari pengertian tersebut maka pariwisata dapat diartikan sebagai suatu perjalanan yang dilakukan berkali-kali, atau berputar-putar, dari satu tempat ke tempat yang lain. Dalam bahasa Inggris disebut juga dengan kata tour, sedangkan untuk pengertian jamak "kepariwisataan" dapat digunakan kata tourisme atau tourism. (Winangsih, 2010:105).

Dalam Undang-undang kepariwisataan No. 10 Tahun 2009, yang dimaksud pariwisata adalah: 1)Wisata adalah kegiatan perjalanan yang dilakukan oleh seseorang atau sekelompok orang dengan mengunjungi tempat tertentu untuk tujuan rekreasi, pengembangan pribadi, atau mempelajari keunikan daya tarik wisata yang dikunjungi dalam jangka waktu sementara. 2)Wisatawan adalah orang yang melakukan wisata. 3)Pariwisata adalah berbagai macam kegiatan wisata dan didukung berbagai fasilitas serta layanan yang disediakan oleh masyarakat, pengusaha, Pemerintah, dan Pemerintah Daerah. 4) Kepariwisataan adalah keseluruhan kegiatan yang terkait dengan pariwisata dan bersifat multidimensi yang muncul sebagai wujud kebutuhan setiap orang dan Negara, serta interaksi antara wisatawan dan masyarakat setempat, sesama wisatawan, Pemerintah, Pemerintah Daerah, dan pengusaha. 5) Daya Tarik Wisata adalah segala sesuatu yang memiliki keunikan, keindahan, dan nilai yang berupa keanekaragaman kekayaan alam, budaya, dan hasil buatan manusia yang menjadi sasaran atau tujuan kunjungan wisata. 6) Daerah tujuan pariwisata yang selanjutnya disebut Destinasi Pariwisata adalah kawasan geografis yang berada dalam satu atau lebih wilayah administratif yang didalamnya terdapat daya tarik wisata, fasilitas umum, fasilitas pariwisata, aksesibilitas, serta masyarakat yang saling terkait dan melengkapi terwujudnya kepariwisataan. 7) Usaha Pariwisata adalah usaha yang menyediakan barang dan/atau jasa bagi pemenuhan kebutuhan wisatawan dan penyelenggaraan pariwisata. 8) Pengusaha Pariwisata adalah orang atau sekelompok orang yang melakukan kegiatan usaha pariwisata. 9) Industri Pariwisata adalah kumpulan usaha pariwisata yang saling terkait dalam rangka menghasilkan barang dan/jasa bagi pemenuhan kebutuhan wisatawan dalam penyelenggaraan pariwisata. 10) Kawasan Strategis Pariwisata adalah kawasan yang memiliki fungsi utama pariwisata atau memiliki potensi untuk pengembangan pariwisata yang memiliki pengaruh penting dalam satu atau lebih aspek, seperti pertumbuhan ekonomi, sosial dan budaya, pemberdayaan sumber daya alam, daya dukung lingkungan hidup, serta pertahanan dan keamanan (UU. Kepariwisataan No.10 Th 2009 Bab I Pasal 1).

Pengertian ini penting dipahami oleh para pelaku di bidang pariwisata, termasuk juga masyarakat. Sehingga mereka juga menyadari bahwa keunikan dan keindahan daerahnya dapat diberdayakan dan dijadikan sebagai komoditas usaha untuk meningkatkan ekonomi masyarakat. Selain itu dengan menyediakan berbagai jenis kuliner yang menjadi ciri khas di daerah wisata tersebut dapat menjadi nilai tambah bagi promosi wisata daerah setempat. 


\section{METODE PENELITIAN}

Metode yang digunakan dalam pembahasan makalah ini, yaitu dengan menggunakan pendekatan kualitatif, metode deskriptif interpretatif. Melalui metode ini diharapkan dapat diketahui bagaimana upaya promosi wisata kuliner yang dilakukan oleh pihak pengembang pariwisata dalam memperkenalkan wisata kuliner kepada masyarakat melalui media online. Untuk mendapatkan data mengenai objek wisata dan upaya yang dijalankan, dilakukan studi literature/kepustakaan, yaitu dari buku-buku yang relevan dan informasi bersumber internet.

\section{HASIL DAN PEMBAHASAN}

Komunikasi pariwisata penting dilakukan untuk mempercepat promosi objekobjek wisata kuliner yang hendak diperkenalkan kepada masyarakat, baik lokal, nasional, maupun internasional. Keberhasilan program pariwisata sangat bergantung pada seberapa gencar pihak-pihak yang terlibat dalam program tersebut melakukan promosi pariwisata terkait objek wisata kuliner yang hendak diangkat.

Ini sangat bergantung pada penggunaan optimal teknologi komunikasi dan juga bagaimana pesan-pesan promosi disusun dan dikelola dengan baik. Saat ini pelaku wisata dimudahkan oleh teknologi melalui pemanfaatan internet dengan beberapa aplikasinya, seperti instagram, facebook, twitter, whatsapp dan lain-lain yang dapat digunakan untuk mempromosikan objek wisata. Promosi pariwisata dapat dilakukan melalui aplikasiaplikasi tersebut. Selain itu pula dengan mengadakan seminar mengenai pariwisata di Banten. Tidak lupa pula peningkatan kerjasama dan pemahaman tentang objek wisata di Banten dengan mitra-mitra terkait, baik dari instansi antara Pemerintah Pusat dengan Pemerintah Daerah merupakan hal yang sangat mendesak, tidak luput pula dengan para tokoh masyarakat untuk menggerakkan masyarakat Banten menggaungkan keindahan objek wisata di Banten. Hal ini diperlukan untuk meningkatkan rasa saling pengertian dan ikut merasa peduli terhadap program menggerakkan pariwisata di Banten dalam rangka melestarikan dan mengenalkan ke tingkat nasional maupun dunia. Kerja sama antar lembaga Pemerintah menjadi peluang untuk mempercepat kemajuan, pertumbuhan dan perkembangan pariwisata secara keseluruhan dalam meningkatkan daya saing pasar regional maupun pasar global melalui peningkatan citra positif pariwisata Banten.

Kembali pada revitalisasi pariwisata di Banten, kiranya langkah promosi yang gencar perlu segera dilakukan. Terkait dengan promosi, tentunya akan berkaitan dengan produk pesan yang dibuat tentang objek wisata di Banten. Seperti yang dikemukakan pada poin 1. Pendahuluan, bahwa promosi sebaiknya dilakukan berkesinambungan sehingga terpaan pesan mengenai informasi tentang pariwisata Banten akan cenderung melekat di benak masyarakat (brand awareness) karena dilakukan berulang-ulang.

Berikut penggunaan media online yang dapat dilakukan untuk promosi wisata kuliner Banten.

Tabel 1. Penggunaan Media Online untuk Promosi Pariwisata Banten

\begin{tabular}{|l|l|l|c|}
\hline \multicolumn{1}{|c|}{ Media } & \multicolumn{1}{|c|}{ Materi } & \multicolumn{1}{c|}{ Action } & Frekuensi \\
\hline Instagram & $\begin{array}{l}\text { Foto: Wisata kuliner khas Banten (sate } \\
\text { bandeng, ketan bintul, dan lain-lain) }\end{array}$ & $\begin{array}{l}\text { Membuat nama dan logo khusus } \\
\text { mengenai Pariwisata Banten }\end{array}$ & Sustainable \\
\hline Twitter & Isi pesan: "MutiaraBanten" & $\begin{array}{l}\text { Membuat tagar wisata kuliner } \\
\text { Banten }\end{array}$ & Sustainable \\
\hline
\end{tabular}




\begin{tabular}{|c|l|l|c|}
\hline Media & \multicolumn{1}{|c|}{ Materi } & \multicolumn{1}{c|}{ Action } & Frekuensi \\
\hline Facebook & Isi pesan: "Banten Kuliner Tour" & $\begin{array}{l}\text { Membuat situs wisata kuliner } \\
\text { Banten }\end{array}$ & Sustainable \\
\hline WhatsApp & $\begin{array}{l}\text { Foto: Wisata kuliner khas Banten (sate } \\
\text { bandeng, ketan bintul, dan lain-lain) }\end{array}$ & $\begin{array}{l}\text { Membuat grup (pemilik restoran, } \\
\text { toko kuliner Banten,dan lain-lain) }\end{array}$ & Sustainable \\
\hline
\end{tabular}

Saat ini Instagram, twitter, facebook, whatsApp merupakan media sosial yang gencar digunakan masyarakat luas. Dengan segala kelebihan dan kelemahannya, paling tidak media ini telah membuktikan bahwa pesan atau informasi akan lebih mudah dan cepat tersebar ke jaringan-jaringan komunikasi. Disamping itu saat ini pengguna internet sudah makin meningkat, sehingga memungkinkan pesan diterima oleh jumlah orang banyak dalam waktu singkat. Melalui media online pula informasi tentang Banten dapat ditampilkan dalam ragam budayanya mengenai objek wisata.

Selain dengan menggunakan media online, promosi pariwisata Banten dapat juga dilakukan dengan mengadakan seminar, workshop, pameran, city tour (ke objek-objek wisata kuliner). Dalam pelaksanaan kegiatan ini diperlukan sejumlah sumber daya yang berkualitas dalam mendukung kesuksesan kegiatan, yaitu sumber daya yang meliputi tenaga ahli dalam melaksakan workshop, seminar, forum-forum sosialisasi; nara sumber yang memiliki kompetensi di bidang marketing communication dan brand marketing. Khusus untuk nara sumber diperlukan orang yang kredibel, melibatkan beberapa tokoh Banten dan selebritas sebagai endorser serta para ahli di bidang komunikasi pariwisata. Daya tarik komunikator juga menjadi bagian dari keberhasilan kampanye pariwisata. Komunikator yang mampu dalam menyampaikan pesan-pesan pariwisata dengan bahasa yang tepat. Tugas mereka tidak mudah dan tidak sesederhana apa yang diucapkan dan dibayangkan orang, memerlukan usaha (effort) yang kuat serta sungguh-sungguh, kemampuan menyosialisasikan dan mengeliminir prasangka dan tudingan miring tentang hal-hal yang melemahkan atas cap yang melekat pada orang Banten sebagai "Jawara" dengan konotasi yang kurang menguntungkan, harus dieliminir dengan publikasi yang luas dan terus menerus dengan menambahkan slogan yang islami, misalnya "Banten Semarak Masjid" atau "Banten Serambi Islam" atau sekaligus mengcounter istilah yang negatif tentang Jawara dengan slogan "Banten itu Ramah" atau "Banten Bersahaja". Jadi sebenarnya banyak yang harus ditata ketika Pemerintah Daerah akan mengangkat ke permukaan berbagai objek wisata yang ada di wilayah Banten. Hal yang paling mendasar adalah mengeliminir anggapan negatif tentang istilah "jawara" itu sendiri. Sehingga yang muncul adalah citra positif secara maksimal, yang pada akhirnya Provinsi Banten dapat maju dan berkembang, terutama dalam hal ini sisi wisata kuliner dan belanja.

Berikut beberapa gambar makanan yang menjadi ciri khas kuliner Banten.
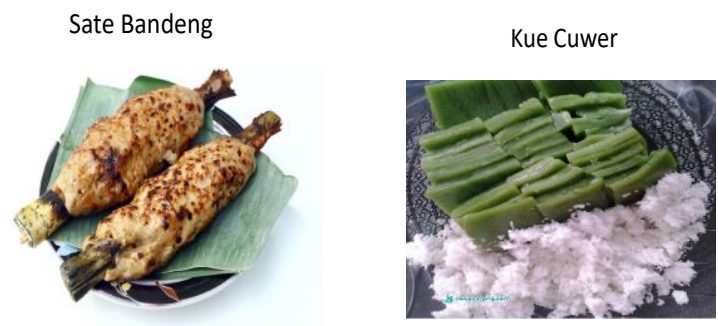

Gambar 2. Makanan ciri khas Banten 


\section{KESIMPULAN}

Dari pembahasan yang telah dipaparkan sebelumnya, dapat ditarik kesimpulan sebagai berikut:

1. Komunikasi menjadi dasar dari segala kegiatan apapun, termasuk dalam bidang pariwisata.

2. Melalui komunikasi yang efektif dan penyusunan pesan serta pengelolaan pesan yang tepat, maka promosi akan tepat sasaran.

3. Diperlukan kerja sama yang serius, sinergis dan terintegrasi antar para pemangku kepentingan dalam upaya promosi wisata kuliner di Banten.

4. Public Relations (PR) sebagai fungsi manajemen mampu menjembatani hubungan antar pemangku kepentingan yang terlibat dalam upaya melakukan revitalisasi wisata kuliner di Banten.

5. Media online menjadi alat promosi yang efektif untuk penyebaran pesan atau informasi wisata kuliner Banten di era disrupsi.

\section{DAFTAR PUSTAKA}

Ardianto, E. (2012). Analisis wacana kritis pemberitaan harian pikiran rakyat dan harian kompas sebagai public relations politik dalam membentuk branding reputation presiden Susilo Bambang Yudhoyono (SBY). Jurnal ilmu komunikasi, 2(1), 1457.

Cutlip, S. M., Center, A. H., \& Broom, G. M. (2005). Effective public relations merancang dan melaksanakan kegiatan kehumasan dengan sukses. Jakarta: PT Indeks Kelompok Gramedia.

Holmes, D. (2005). Communication theory: Media, technology and society. Sage.

Irianto, D. (2017). Industry 4.0; the challenges of tomorrow. In Disampaikan pada Seminar Nasional Teknik Industri, Batu-Malang.

Kiranasari, B., WIRATMOJO, Y. B., \& MA, S. (2014). Faktor-faktor yang Menentukan Online Seller Memilih Situs Jejaring Instagram Sebagai Media Promosi Online shop.

Löffler, M., \& Tschiesner, A. (2013). The Internet of Things and the future of manufacturing. McKinsey \& Company, 4.

Mulyana, D. (2005). Ilmu Komunikasi: Suatu Pengantar, Remaja Rosdakarya.Nasrullah, Rulli. 2012. Komunikasi Antar budaya di Era Budaya Siber. Prenada Media Group. Jakarta.

Shimp, T. A. (2003). Periklanan Promosi Komunikasi Pemasaran. Terpadu, edisi ke, 5.

Suryana, A. (2001). Marketing Communications Effectiveness in Small and Medium Enterprises (SMEs) in Bandung. Mediator: Jurnal Komunikasi, 2(2), 303-324.

Syam, N. W. (2015). Komunikasi Transendental Perspektif Sains Terpadu. Bandung: PT. Remaja Rosdakarya.

UU. Kepariwisataan No.10 Th 2009 Bab I Pasal 1 